Proc. Estonian Acad. Sci. Eng., 2004, 10, 4, 308-314

\title{
Performance of hard alloys in abrasive-erosive and sliding wear conditions
}

\author{
Jakob Kübarsepp, Heinrich Klaasen and Vello Vainola \\ Department of Materials Engineering, Tallinn University of Technology, Ehitajate tee 5, 19086 \\ Tallinn, Estonia; jakob@edu.ttu.ee \\ Received 1 July 2004

\begin{abstract}
The wear behaviour of some carbide composites differing in composition and structure (WC hardmetals, TiC and $\mathrm{Cr}_{3} \mathrm{C}_{2}$ cermets), has been investigated in abrasive-erosive and sliding wear conditions. Comparative trials in the same conditions with tool steels, complemented by SEM studies, have been performed. It has been shown that in abrasive-erosive as well as in sliding wear conditions the performance of a hard alloy (carbide composite, tool steel) is controlled primarily by its carbide phase (its properties and amount in the alloy).
\end{abstract}

Key words: abrasive-erosive wear, sliding wear, cemented carbides, tool steels.

\section{INTRODUCTION}

Carbide composites (hardmetals and cermets) and high-speed steels are most widely used for wear applications. Hardmetals and high-speed steels are used in all types of wear conditions, including abrasive, sliding and erosive wear. Major applications of tungsten carbide based hardmetals cover metal-removal cutting tools, rock- and earth-drilling tools, sheet metal forming tools, etc. $\left.{ }^{1}\right]$. Cermets (TiC-NiMo and TiCN-NiMo alloys) are used in restricted application areas. Steel-bonded composites are also well known among titanium carbide based composites $\left[{ }^{2,3}\right]$. Selection of a composite, reliable in given working conditions, is difficult because of inadequate information about the wear resistance of ceramic and metal composites. Furthermore, available information is sometimes contradictory. Contradictory are also results about the influence of structural and mechanical characteristics on the resistance to wear. Influence of the size of the carbide grain on the abrasive wear resistance is an example for that $\left[{ }^{4}\right]$. 
No systematic information is available about the wear resistance of different wear-resistant materials, particularly of cemented carbides and tool steels in different wear conditions. Therefore the aim of this study is to test (and map) wear resistance of different powder composites (cemented carbides) and tool steels in different wear conditions, particularly in abrasive-erosive and sliding wear.

\section{EXPERIMENTAL DETAILS}

\subsection{Materials}

Tungsten, titanium and chromium carbide based cemented carbides were investigated. Composition, structural characteristics and main mechanical properties of these composites are shown in Table 1. Composition and some properties of thermally treated tool steels investigated are given in Table 2.

Table 1. Composition and properties of cemented carbides $(H V$ - Vickers hardness, HRA Rockwell hardness, $R_{T Z}-$ transverse rupture strength)

\begin{tabular}{|c|c|c|c|c|c|c|c|}
\hline \multirow[t]{2}{*}{ Grade } & \multicolumn{3}{|c|}{ Carbide phase } & \multirow[t]{2}{*}{ Binder } & \multirow[t]{2}{*}{$H V, \mathrm{MPa}$} & \multirow[t]{2}{*}{$H R A$} & \multirow{2}{*}{$\begin{array}{l}R_{\mathrm{TZ}}, \\
\mathrm{GPa}\end{array}$} \\
\hline & Types & $\%$ & $d, \mu \mathrm{m}$ & & & & \\
\hline H8 & WC & 92 & 2.2 & $\mathrm{Co}(\mathrm{W})$ & 1430 & 90.7 & 1.9 \\
\hline $\mathrm{H} 10$ & WC & 90 & 2.1 & $\mathrm{Co}(\mathrm{W})$ & 1350 & 89.0 & 2.3 \\
\hline H15 & WC & 85 & 2.1 & $\mathrm{Co}(\mathrm{W})$ & 1140 & 87.5 & 2.9 \\
\hline $\mathrm{H} 20$ & WC & 80 & 2.2 & $\mathrm{Co}(\mathrm{W})$ & 960 & 85.0 & 3.0 \\
\hline $\mathrm{H} 12 \mathrm{~F}$ & WC & 88 & 1.7 & $\mathrm{Co}(\mathrm{W})$ & 1320 & 89.0 & 3.0 \\
\hline $\mathrm{H} 15 \mathrm{~F}$ & WC & 85 & $<1.0$ & $\mathrm{Co}(\mathrm{W})$ & 1380 & 89.5 & 3.5 \\
\hline T60/FeNi8 & $\mathrm{TiC}$ & 60 & 2.2 & $\mathrm{Fe}+8 \% \mathrm{Ni}$, martensite & 1210 & 88.3 & 2.4 \\
\hline T70/FeNi8 & $\mathrm{TiC}$ & 70 & 2.2 & $\mathrm{Fe}+8 \% \mathrm{Ni}$, martensite & 1360 & 89.5 & 1.9 \\
\hline T60/FeNil4 & $\mathrm{TiC}$ & 60 & 2.1 & $\mathrm{Fe}+14 \% \mathrm{Ni}$, austenite & 1100 & 86.5 & 2.3 \\
\hline T70/FeNil4 & $\mathrm{TiC}$ & 70 & 2.2 & $\mathrm{Fe}+14 \% \mathrm{Ni}$, austenite & 1260 & 88.7 & 2.3 \\
\hline TN30 & $\mathrm{TiC}$ & 70 & 2.0 & $\mathrm{Ni}: \mathrm{Mo}=2: 1$ & 1420 & 89.7 & 1.6 \\
\hline TN40 & $\mathrm{TiC}$ & 60 & 2.2 & $\mathrm{Ni}: \mathrm{Mo}=2: 1$ & 1260 & 88.4 & 2.0 \\
\hline TN50 & $\mathrm{TiC}$ & 50 & 2.1 & $\mathrm{Ni}: \mathrm{Mo}=2: 1$ & 1000 & 87.5 & 2.1 \\
\hline $\mathrm{C} 10$ & $\mathrm{Cr}_{3} \mathrm{C}_{2}$ & 90 & 5.0 & $\mathrm{Ni}: \mathrm{Mo}=2: 1$ & 1420 & 90.7 & 0.6 \\
\hline $\mathrm{C} 20$ & $\mathrm{Cr}_{3} \mathrm{C}_{2}$ & 80 & 4.5 & $\mathrm{Ni}: \mathrm{Mo}=2: 1$ & 1300 & 89.5 & 0.9 \\
\hline $\mathrm{C} 30$ & $\mathrm{Cr}_{3} \mathrm{C}_{2}$ & 70 & 4.1 & $\mathrm{Ni}: \mathrm{Mo}=2: 1$ & 1110 & 87.0 & 1.2 \\
\hline
\end{tabular}

Table 2. Composition and properties of tool steels

\begin{tabular}{|c|c|c|c|c|c|c|c|c|c|}
\hline \multicolumn{2}{|c|}{ Steel grades* } & \multicolumn{5}{|c|}{ Compostion, mass $\%$} & \multirow[t]{2}{*}{$H R A$} & \multirow{2}{*}{$\begin{array}{l}H V, \\
\mathrm{MPa}\end{array}$} & \multirow{2}{*}{$\begin{array}{l}R_{\mathrm{TZ}} \\
\mathrm{GPa}\end{array}$} \\
\hline Uddeholm & Grade & $\mathrm{C}$ & $\mathrm{Cr}$ & $\mathrm{W}$ & Mo & $\mathrm{V}$ & & & \\
\hline Arne & K460 & 1.0 & 0.5 & 0.6 & - & - & 82.0 & 820 & 4.2 \\
\hline Rigor & K305 & 1.0 & 5.1 & - & 1.0 & 0.2 & 80.0 & 800 & 4.4 \\
\hline Sverker & K110 & 1.5 & 12 & - & 0.8 & 0.8 & 81.5 & 800 & 4.5 \\
\hline ASP23 & HSS1 & 1.3 & 4.2 & 6.5 & 5.0 & 3.0 & 84.5 & 900 & 4.7 \\
\hline ASP60 & HSS2 & 2.3 & 4.0 & 6.5 & 7.0 & 10 & 86.5 & 1100 & 4.8 \\
\hline
\end{tabular}

* Varastoluettelo (steel classification) STEN, 1998. 


\subsection{Testing conditions}

Transverse rupture strength $R_{\mathrm{TZ}}$ was tested in accordance with the standard ISO332. Vickers hardness was determined in accordance with the standard ENISO6507-1. Wear behaviour was studied in abrasive-erosive and sliding wear conditions. The abrasive-erosive wear was investigated using a centrifugal accelerator in accordance with the Russian standard GOST 23.201-78 (using silica sand with particle size of $0.1-0.3 \mathrm{~mm}$ as abrasive) $\left[^{5}\right]$. The velocity of the abrasive jet was $80 \mathrm{~m} / \mathrm{s}$ and angle of attack $30^{\circ}$. Erosive wear $K$ was considered as volumetric wear in $\mathrm{mm}^{3}$ per $1 \mathrm{~kg}$ of abrasive. Relative wear resistance $X$ was calculated with regard to normalized carbon steel $(0.45 \% \mathrm{C})$. The number of specimens per a testing point was 4 .

Sliding wear in dry conditions without abrasive was tested in accordance with the ASTM standard B611-85. Wear rate was considered as volumetric wear in $\mathrm{mm}^{3}$, generated during the sliding distance of $4000 \mathrm{~m}$ at the load $F=40 \mathrm{~N}\left[{ }^{6}\right]$.

\section{RESULTS}

\subsection{Abrasive-erosive wear}

Results of the tests show a shortcoming of the hardness as a characteristic used for wear resistance prognosis. Wear resistance between cemented carbides, based on different carbides, may differ up to three times (Fig. 1). Results confirm advantages of tungsten carbide based composites over tungsten-free cermets $\left[{ }^{7,8}\right]$.

The higher the hardness (content of carbides), the higher is the advantage in wear performance of WC hardmetals over titanium and chromium carbide cermets (at equal hardness). Despite the differences in the composition of the carbide (titanium or chromium carbide) and binder (Fe-Ni steels or Ni-Mo alloy), no pronounced difference exists in wear behaviour between different tungsten carbide free cermets (at equal hardness).

As expected, the erosion resistance of tool steels is considerably lower than that of cemented carbides. Low

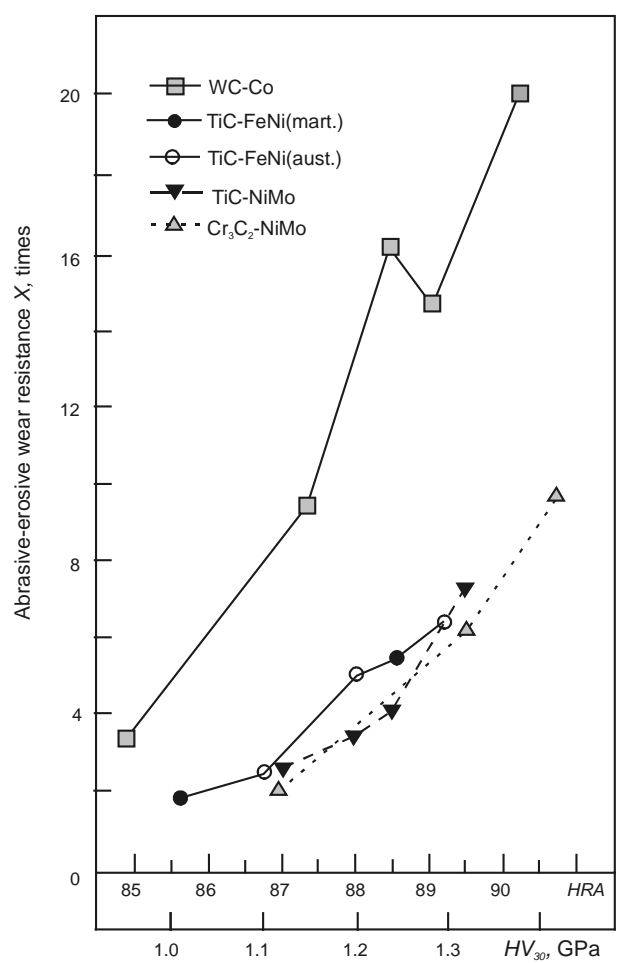

Fig. 1. Dependence of the abrasive-erosive wear resistance on the hardness of WC-, TiC- and $\mathrm{Cr}_{3} \mathrm{C}_{2}$-based cemented carbides. 
effectiveness of alloying the steels should be pointed out. The advantage of highalloyed high-speed steels ASP60 over the low-alloyed tool steel ARNE is only 1.8 times (Fig. 2).

Thus our results show a prevailing influence of the content and properties of the carbide phase on the wear resistance of carbide composites. The influence of binder characteristics is of minor importance (Fig. 1).

Stiffness (characterized by the modulus of elasticity) of an alloy, that is its resistance to elastic and plastic strain, seems to be of crucial importance when abrasive-erosive wear is considered. Stiffness of a composite depends primarily on that of the carbide phase and its content in the alloy. A good correlation between the modulus of elasticity and erosive wear resistance of the alloys considered proves this conclusion (Fig. 3).

Attempts have been made to find a relationship between abrasive-erosive wear resistance and fracture toughness of brittle ceramic materials. Such a relationship has not been found when ceramic and metal composites are considered [ $\left.{ }^{9}\right]$.

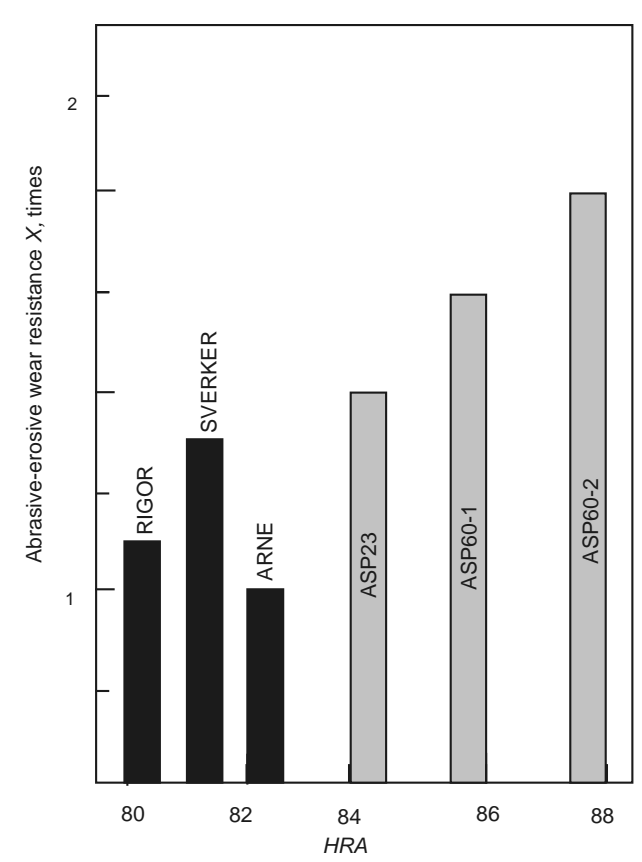

Fig. 2. Abrasive-erosive wear resistance vs hard- Fig. 3. Modulus of elasticity $E$ and abrasiveness of tool steels; ASP60-1 - low-temperature erosive wear resistance $X$ of some carbide heat treatment, ASP60-2 - high-temperature heat composites based on $\mathrm{TiC}, \mathrm{WC}, \mathrm{Cr}_{3} \mathrm{C}_{2}$ and hightreatment.

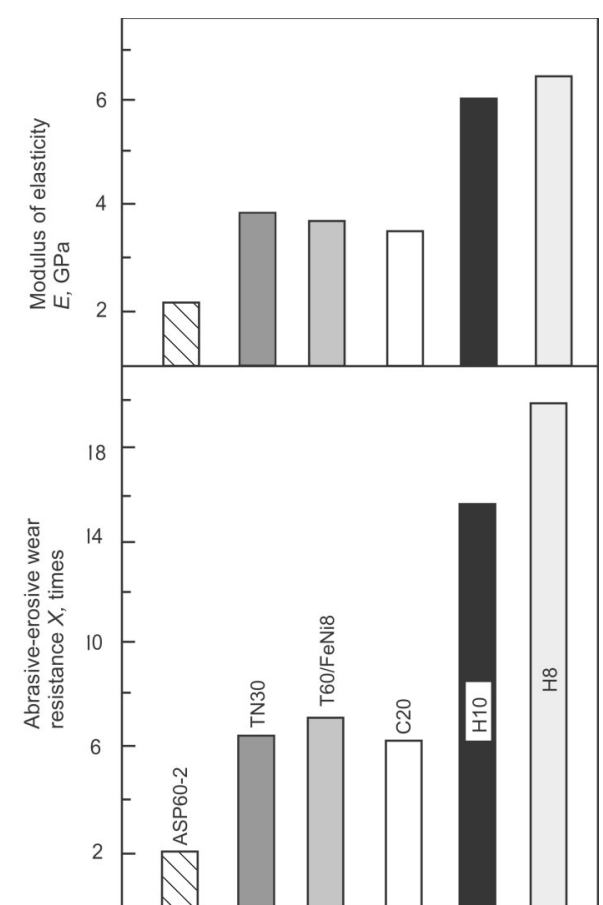
speed steel ASP60. 


\subsection{Sliding wear}

Testing results in sliding wear conditions are somewhat similar to those in abrasive-erosive wear: hardness has limits as a characteristic used for the assessment of the wear rate and wear resistance. Results in Fig. 4 confirm the advantage of WC-based hardmetals over tungsten-free cermets. However, the superiority of the tungsten carbide based composites does not exceed 1.7 times over titanium carbide based cermets.

Characteristically, the influence of an increase in the carbide content (and hardness) of WC- and TiC-based cermets on the wear rate (and wear resistance) is much lower than in the conditions of erosive wear. Additional characteristic of the sliding wear is extremely low wear resistance of chromium carbide based cermets. It is of importance to point out that wear resistance of such alloys decreases when carbide content and hardness increase (Figs. 4 and 5). It is also of importance that TiC-FeNi steel cermets, unlike abrasive-erosive wear conditions, have an advantage over the TiC-NiMo cermets.

Sliding wear resistance of tool steels is lower than that of the WC- and TiCbased ceramic and metal composites. However, unlike abrasive-erosive conditions, the degree of alloying has a marked influence on the wear resistance of tool steels. The difference in the wear rate of low- and high-alloyed steels exceeds six

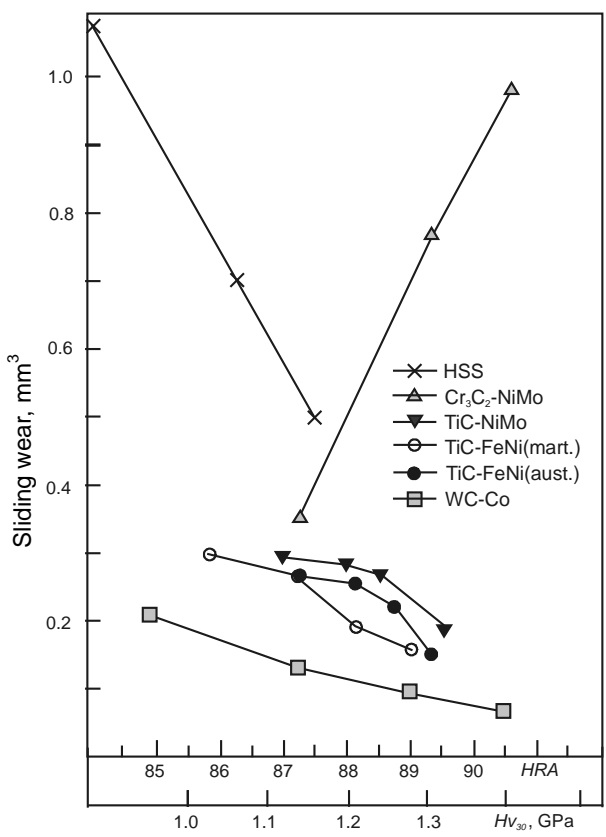

Fig. 4. Dependence of the sliding wear on the hardness of TiC-, WC- and $\mathrm{Cr}_{3} \mathrm{C}_{2}$-based cemented carbides and high speed steels (HSS).

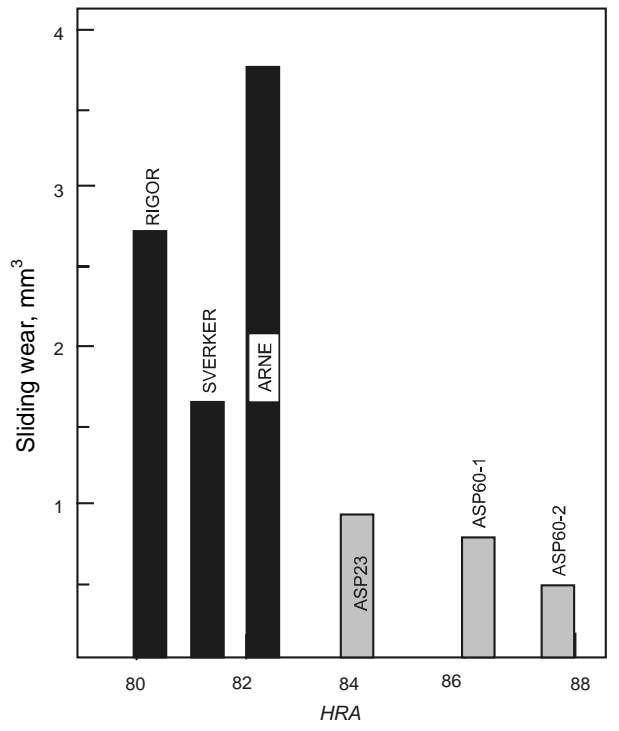

Fig. 5. Sliding wear rate vs hardness of tool steels: ASP60-1 - low-temperature heat treatment, ASP60-2 - high-temperature heat treatment. 
times (in abrasive erosion only 1.8 times). In sliding wear conditions, the highalloyed high-speed steels have an advantage over chromium carbide based cermets.

The performance of carbide composites (and tool steels) in conditions of sliding wear, in contrast to abrasive-erosive wear, depends to a great extent on the alloy and its carbide phase strength properties (Table 2, Figs. 4 and 5).

\section{CONCLUSIONS}

1. WC-based cemented carbides have advantages over tungsten-free cermets both in abrasive-erosive (up to 3 times) and sliding (up to 1.7 times) wear conditions.

2. Titanium and chromium carbide based cermets, bonded with the Ni-Mo alloy, are similar to TiC-FeNi cermets in abrasive-erosive and less efficient in sliding wear conditions.

3. Tool steels compare unfavourably with carbide composites in abrasiveerosive wear. High-speed steels have advantages over chromium carbide based cermets and have wear resistance close to titanium carbide based ones in sliding wear conditions.

4. Prognosis of wear resistance on the basis of hardness can lead to pronounced mistakes when carbide composites and tool steels of different composition are considered.

5. The performance of hard alloys in abrasive-erosive wear conditions depends on the alloy stiffness (its resistance to elastic-plastic strain) and is controlled primarily by stiffness (modulus of elasticity) and content of the carbide phase.

6. The performance of a hard alloy in conditions of sliding wear depends to a great extent on the alloy (and its carbide phase) strength properties.

\section{ACKNOWLEDGEMENT}

This work was supported by the Estonian Science Foundation (grants Nos. 4850 and 5882).

\section{REFERENCES}

1. Brookes, K. J. A. Hardmetals and other Hard Materials. International Carbide Data, London, 1992.

2. Kübarsepp, J. Steel Bonded Cermets. Valgus - Tallinn Technical University, Tallinn, 1991.

3. Nabb, R. Advantages of Ferro-Titanit for metal working industry. Met. Powder Rep. 1988, 43, 198-199.

4. Komac, M. and Novak, S. Mechanical and wear characteristics of Titanium Carbide-base Cermets. Int. J. Refr. Met. and Hard Mater., 1985, 4, 21-26. 
5. GOST 23.201-78 Wear resistance assurance. Gas-abrasive wear testing of materials and coatings with centrifugal accelerator. Gosudarstvennyj Komitet SSSR po Standartam, Moscow, 1978 (in Russian).

6. Hutchings, J. Tribology: Friction and Wear of Engineering Materials. CRS Press, Cambridge, 1992.

7. Kübarsepp, J., Reshetnyak, H. (Klaasen, H.) and Annuka, H. Characterization of the serviceability of steel-bonded hardmetals. Int. J. Refr. Met. \& Hard Mater., 1993-1994, 12, 341-348.

8. Reshetnyak, H. (Klaasen, H.) and Kübarsepp, J. Mechanical properties of hard metals and their erosive wear resistance. Wear, 1994, 177, 185-194.

9. Hussainova, J. Effect of microstructure on the erosive wear of titanium carbide-based cermets. Wear, 2003, 255, 121-128.

\title{
Kõvasulamite töövõime abrasiivse erosiooni ja liugkulumise tingimustes
}

\author{
Jakob Kübarsepp, Heinrich Klaasen ja Vello Vainola
}

Töös vaadeldakse erineva koostise ja struktuuriga karbiidkomposiitide (WCkõvasulamid, TiC- ja $\mathrm{Cr}_{3} \mathrm{C}_{2}$-kermetid) ja tööriistateraste kulumismehhanismi abrasiivse erosiooni ja liugkulumise tingimustes. On selgitatud, et kõvasulamite (karbiidkomposiitide ja tööriistateraste) töövõime nii abrasiivsel erosioonil kui ka liugkulumisel on määratud nende karbiidse faasi omadustega (jäikus, tugevus) ja kogusega sulamis. 